\title{
Theinfluence Of Entry Order With Market Share Moderated By Technology Change Case In Manufacture Industries At Indonesia
}

\author{
Satria Tirtayasa \\ \{satriatirtayasa@umsu.ac.id\} \\ University of Muhammadiyah Sumatera Utara, Indonesia
}

\begin{abstract}
The changes in business environment cancreate an opportunity for the firms to become the pioneer or follower in achieving market share. Previous studies about entry order (pioneer and follower) and market share were done either in fully developed or developed economic settings. None has taken place in an emerging or developing economic, particularly Indonesia. Indonesian manufacture industries were important economic sectorin the nation development. Thus, this study intends to examine the relationship between entry order and market share. Furthermore, this study also investigate the moderating of technology change. Data were collected through mail survey and personal interviews addressed to $110 \mathrm{CEOs}$. The research hypotheses were tested by using Hierarchical Regression Analysis (HRA). The study generates three major findings. Firstly, the research proves that pioneer and early follower are significant differences withmarket share and than pioneer company performs better than early follower. Secondly, this research found that there is a positive relationship between entry orderwith market share.Thirdly, the research found that technology change positive and significant influence the relationshif of entry order and market share.
\end{abstract}

Keywords: Entry order, Market Share, Technology Change

\section{Introduction}

No doubt, time of company enter to the market is on of strategy for the company to be success to have high market share. In many cases, first firm company enter to the market generally have status as market leader. (Miller, William, and Robert, 1989) first movers have higher market share than early followers. In turn they have higher market share than later entries. Meanwhile, Urban and Star (1991) investigated first firm to enter the market for specific products or services will have the advantages from the rivals.

The business of environment changes such as technology changes and customer needgiving animpact on competitive advantage of business. This technology change remain companies about their position in the market, whether they have a high market share or not. Thus, can showed that with application of technology can destrupt the competitor, example : Nokia with famous with fashion hand phone already beated by Apple with smart phone, news paper lost their market share because of on line news paper, and may more. Thus, can be concluded that with technology change can appear the innovation of firm and with innovation the firm can achieve high market share. More innovative the company can give opportunity to be a leader in the business. (Carpenter and Nakamoto, 1989; (Shankar, V., Carpenter, G.S. \& Krishnamurthi, 1998)found that a follower uses product innovation strategy cangive a chance to overtake the pioneer. 
Studies about entry order in Indonesian manufacture industry need to be conducted because they contribute to the country's revenue and this industry also shows expansion).Based on the BPS ( Statistic Central Bureau), The contribution manufacture industries for Indonesia PDB in 2015 was about 17.8\% and increase 18,1\% in the 2016 about US\$ 2.80 billion. The highest contribution is processing industry about $20,8 \%$ and for non processing industry, the food and beverage industry give highest contribution a bout $(30,84 \%)$. According economy ministry want to increase the contribution of manufacturing industry more than $30 \%$. Thus, bases on this condition can be concluded that manufacturing industries have many competitor not only in Indonesia market but also in international market.

Based on the problem aboved, the research problem that could arise is "does the combination of firm timing decision with tecnnologychangedrive market share ?".

Based on the problem statement and importance of this research, the following research questions are required to be addressed :

- To what extent is the different of entry order onmarket share ?

- To what extent does entry order influence market sharee ?

- Does the interaction between entry order and technology change effectmarketshare ?

\section{Literature Review}

\subsection{Entry order of Business}

Entry order is meaning thatthe first time a business enter to the market . (Robinson and (Fornell, C., Robinson, W.T. \& Wernerfelt, 1985)and thanentry order as a categorical that devidedof a market pioneer, an early follower, or a late entrant. Meanwhile, Szymanski, Troy, and(Szymanski, D. M., Troy, L. C. \& Bharadwaj, 1995), define entry order as the first mover entering the market under ideal conditions.

\subsection{Pioneer and Entry Follower}

PIMS defines market pioneer as " one of the pioneers in developing such as product or service". Meanwhile, Robinson and (Fornell, C., Robinson, W.T. \& Wernerfelt, 1985)defines the pioneers in the first developing such as products or services". Robinson, et al. (1992) are also define that 'first mover' as the first business to develop products and services. Early follower' is the business make the products and services after the first mover enters the market.

\subsection{Order of Entry And Market Share}

(Parry, M. \& Frank, 1990)have studied 593 consumer goods business and 1287 industrial goods business and their findings are as follows : 1.The followers were obtained low market shares than pioneer. 2.The pioneers have shared advantage depends on industry type (concentrated, non concentrated and end user purchase amounts.

(Fornell, C., Robinson, W.T. \& Wernerfelt, 1985)have investigated Industrial goods and consumer goods. The researchers have used the following categories : the first entrant market pioneers, other market pioneers, early followers, and late entrants. The research findings are as follows :Market pioneers do not tend to benefit from acquisition entry and increase finance skills significantly increases the probability of being a first entrant and of being another market pioneer.(Robinson, W.T. \& Huff, 1994) have studied data by covering 95 observations in 34 product categories of frequently purchased consumer goods. The results is the pioneer market share reward show an increase when lead time is increased. Srinivasan and 
Murthi (1996) have analyzed managerial skills in determining the first mover market share advantages. The sample consist of 236 business unit from PIMS data base. The findings are as follows : the difference in the RME (relative marketing efficiency) scores between the pioneers and late entrants is significant and the difference in Relative production efficiency (RPE) score between pioneers and early followers and late entrant are significant.(Shankar, V., Carpenter, G.S. \& Krishnamurthi, 1998) have analyzed 13 brands from two categories of ethical drugs in U.S. market during the 1970s and 1980s. The findings of the research are : a) The pioneer has higher market share than non innovative late mover.

\subsection{Moderators Effect of Technology}

(Slater, S. F. \& Narver, 1994)studied found that technology turbulent have significant relationship with sales growth, competitive intensity was found no moderating effect of the market orientation relationship with market performance.

\section{Hypotheses Development}

\subsection{Entry order and Market Share}

In order to determine whether the findings established are suitable and relevant to the theoretical framework, this research uses previous evidence to develop hypotheses. In past studies, the relationship between entry order andmarket share revealed an equivocal results. For instance,(Fornell, C., Robinson, W.T. \& Wernerfelt, 1985); Urban, Carter, Gaskin and Zofia(1986); Lambkin(1988); Carpenter and Nakamoto(1989), and Michell(1991) found that entry order as having significant effects on business performance. On the contrary, (Freshtman, 1990) (Shankar, V., Carpenter, G.S. \& Krishnamurthi, 1998); Carpenter and Sawhney, 1996 shows that early entry beat pioneers to have high market share with product innovation strategy.

\subsection{Moderator Effect of Technology Change with Entry order and Market Share Performance}

State that the greater the rate of technological change, the greater the advantages to late entrants. Access to newer technologies may offer later entrants the opportunity to overcome the negative experiences of the pioneer and learn from the advantages enjoyed by the pioneer. For the first mover, investments in existing technologies could become a barrier to exit (Szymanski, et al.,1995). On the contrary, businesses which operate by using stable technologies need to rely on market orientation to a greater degree to obtain a competitive edge because technology does not provide such leverage (Bennet and Cooper, 1981).

Based on the above discussion, a research framework has been developed (see figure 1). 


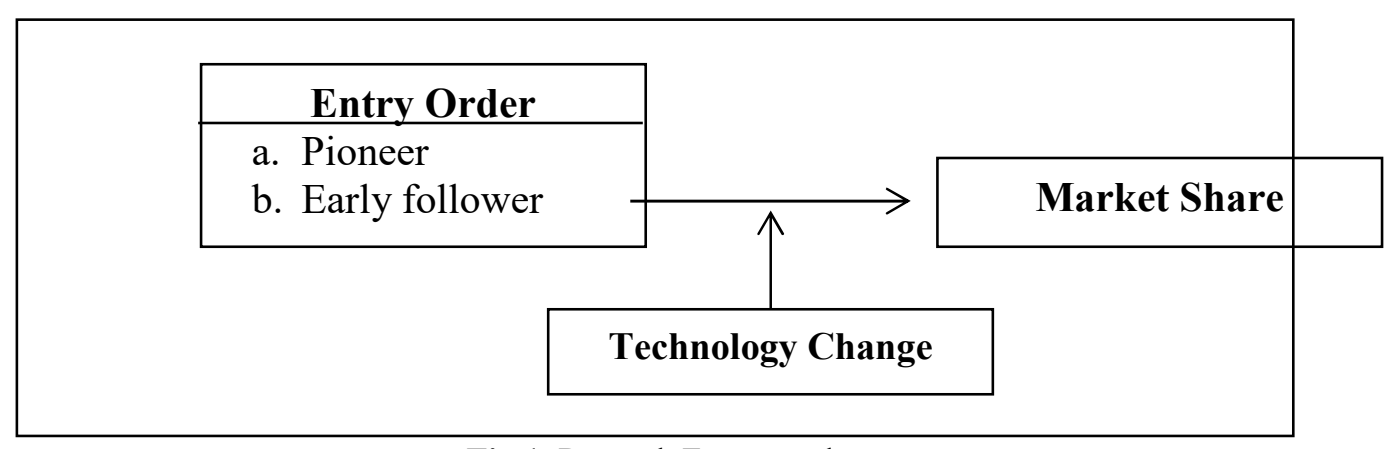

Fig.1. Reseach Framework

\section{Methodology}

The study employed the survey method using a structured mail questionnaire (Sekaran, 2003). This is the most appropriate method for drawing responses when geographical dispersion is large, such as the case of indonesia (Sekaran, 2003). The survey questionnaire gathered information on Company Characteristic, Market Place factors, and Market Share. The extent of mark place factors were adopted from Kohli and Jaworski (1993) and the responses were elicited on a 5 point of scale (Likert Scale). A total 110 questionnaires were collected from respondents of manufacture companies listed in the Indonesia Manufacturing Directory released by central Bureau Statistics (Biro Statistik) 2017.

\subsection{Population and Sample}

Based on BPS sources the amount of population of manufacture industry at West JavaIndonesia are 240 manufacture industry (textiles companies, food and beverage, chemical industry, processing industry). Moreover, The researcher chooses large manufacture industries as the populationbecause they have their own marketing divisions that always control the marketing strategies and adapt technology as well (purposive sampling) The sample size are 110 companies.

\subsection{Data Collection}

The questionnaire uses the Indonesian Language for the research conducted in Indonesia because the respondents would be able to comprehend the contents.

\begin{tabular}{|c|c|c|c|}
\hline No. & Variables & Items & $\begin{array}{c}\text { Cronbach } \\
\text { Alpha }\end{array}$ \\
\hline 1 & $\begin{array}{l}\text { Technologic } \\
\text { al } \\
\text { Turbulence }\end{array}$ & 4 & 0.7202 \\
\hline 2 & $\begin{array}{l}\text { Market } \\
\text { share }\end{array}$ & 3 & 0.8990 \\
\hline
\end{tabular}




\subsection{Statistical Methods}

The researcher uses a hierarchical regression analysis (HRA) to test the effect of the moderator variables (technology change). The equations are follows :

(1) $\mathrm{Y}=\beta 0+\beta 1 \mathrm{OE}$

(2) $\mathrm{Y}=\beta 0+\beta 1 \mathrm{OE}+\beta 2 \mathrm{MPF}$

(3) $\mathrm{Y}=\beta 0+\beta 1 \mathrm{OE}+\beta 2 \mathrm{MPF}+\beta 3 \mathrm{OEMPF}$

Where :

$\mathrm{Y} \quad=$ Market share

$\mathrm{OE} \quad=$ Entry order

MPF $=$ technology change

OEMPF $=$ interaction between entry order and technology change.

\section{Findings}

\subsection{Differences ofEntry order and Market Share}

The difference between entry order and market share. The result reveals that pioneer and early follower has significant differences in achieving market share (see Table 2).

Table 2.Differences Entry order and Market Share

\begin{tabular}{llcc}
\hline Variable & \multicolumn{1}{c}{ Sample } & $\begin{array}{c}\text { Mean } \\
\text { Score }\end{array}$ & $\begin{array}{c}\text { Significan } \\
\text { t-t }\end{array}$ \\
& & & \\
Market & -Pioneer & 3.729 & 0.000 \\
share & -Early & 7 & 0.000 \\
& Follower & 3.125 & \\
& & 0 & \\
\hline
\end{tabular}

\subsection{Technology Change}

When technologychange is introduced as moderator factor the $\mathrm{R}^{2}$ increases from .091 to .118 or $\mathrm{R}^{2}$ changes .0027 and is significant at 10 percent level or significant $\mathrm{F}$ changes by .074. Partial regression shows .233 and the coefficient is significant at 10 percent level or significant-t show .074 (see table 3). Whenentry order and technology change interact, $\mathrm{R}^{2}$ increases from .118 to .177 or $\mathrm{R}^{2}$ changes .059 and significant at 5 percent level or significant $\mathrm{F}$ changes to .007 . The interaction is 0.105 and significant-t of .007 . Conversely, from the regression analysis above, it could be stated that technology change has a strong contribution toward the interaction role, and hypothesis is accepted. 
Table 3.Entry order and Market Share Moderated by Technology Change

\begin{tabular}{clcccc}
\hline $\begin{array}{c}\text { No. } \\
\text { Model } \\
1\end{array}$ & \multicolumn{1}{c}{ Variables } & $\begin{array}{c}\text { Coefficie } \\
\mathbf{n t}\end{array}$ & $\begin{array}{c}\text { Standard } \\
\text { Error }\end{array}$ & $\begin{array}{c}\mathbf{t}- \\
\text { Value }\end{array}$ & $\begin{array}{c}\text { Significant } \\
\mathbf{- t}\end{array}$ \\
& (Constant) & 2.289 & 0.515 & 4.446 & 0.000 \\
& Entry order & 0.213 & 0.069 & 3.065 & 0.003 \\
& Technology & 0.233 & 0.129 & 1.803 & 0.074 \\
& Change & & & & \\
& $\mathrm{R}^{2}$ & 0.118 & & & \\
& $\mathrm{R}^{2}$ change & 0.027 & & & \\
& Sig. F change & 0.074 & & & \\
2 & (Constant) & 2.206 & 0.501 & 4.406 & 0.000 \\
& Entry order & 0.142 & 0.072 & 1.959 & 0.053 \\
& Technology & 0.230 & 0.126 & 1.834 & 0.069 \\
& Change & & & & \\
& Interaction & 0.105 & 0.039 & 2.728 & 0.007 \\
& $\mathrm{R}^{2}$ & 0.177 & & & \\
& $\mathrm{R}^{2}$ change & 0.059 & & & \\
\hline Sig. F change & 0.007 & & & \\
\hline
\end{tabular}

\subsection{Discussion}

The evidence shows that pioneer and early follower has difference performance in . achieving market share than early follower. Furthermore, the evidence reveals that entry order and market share has positive relationship.The findings is supported byMiller, et.all, 1989 and Urban and Star, 1991, where they stated that first entry company have high market share than followers company.

Secondly, hierarchy regression test found that technology change positively moderate the relationship between entry order and market share.The findings also supported by Kohli and Jaworski,1993, (Adu, 1997), where they found thatthe greater extent of technology change, could made more highest the relationship of entry order and market share.

Can not be denied that the role of technology change (innovation) is very important for manufacture industries in Indonesia in increasing their market share.If the manufacture industries late to make innovation, it can caused their market share will decrease. Therefore, pioneer and follower industries should improve their technology to make product innovation and efficiency.

\section{References}

[1] Adu, A. \& K. (1997) 'Market orientation and Performance: Do the Findings Established in Large Firms Hold in the Small Business Sector', Journal of Euro marketing, Vol.6(1), pp. 1-26.

[2] Fornell, C., Robinson, W.T. \& Wernerfelt, B. (1985) 'Consumption Experience And Sales Promotion Expenditure', Management Science, Vol.31 sep(No.9), pp. 10841105.

[3] Parry, M. \& Frank, M. . (1990) 'When to Lead or Follow? it Depends, Marketing Letters', Marketing Letters, 1 (Novembe, pp. 187-198.

[4] Robinson, W.T. \& Huff, L. C. (1994) 'The Impact of Lead Time and Years of Competitive Rivalry on Pioneer Market Share Advantages', Management Science, 40 (Octobe, pp. 1370-1377. 
[5] Shankar, V., Carpenter, G.S. \& Krishnamurthi, L. (1998) 'Late Mover Advantage: How Innovative Late Entrants Outsell Pioneers', Journal of Marketing Research, pp. $1-14$.

[6] Slater, S. F. \& Narver, J. C. (1994) 'Does Competitive Environment Moderate The market Orientation-Performance Relationship', Journal of Marketing, pp. 46-55.

[7] Szymanski, D. M., Troy, L. C. \& Bharadwaj, S. G. (1995) 'Order of Entry and Business Performance: An Empirical Synthesis and Reexamination', Journal of Marketing, 59 (Octobe, pp. 17-33.

[8] Emory, C. W. \& Cooper, D.R.,1995. Business Research Methods, Fifth Edition, Richard D. Irwin, Inc.

[9] Fershtman, C., Mahajan, V. \& Muller, E.,1990. Market Share Pioneering Advantage: a Theoretical Approach, Management Science, 36 (August), 900-918.

[10] Flaherty, M. T., 1983. Market Share, Technology Leadership, and Competition in International Semiconductor Markets, In Research on Technological Innovation, Management and Policy, R .Rosenbloom, ed. Greenwhich, CT: JAI Press Inc., 69-102.

[11] Gregory, V.S., Carpenter, G. S. \&Krishnamurti, L., 1998. Late Mover Advantage: How Innovative Late Entrants Outsell Pioneers, Journal of marketing Research, Chicago, 35 (February), 54-70.

[12] Jaworski, B. J. \&Kohli, A.K.,1993. Market Orientation: Antecedents and Consequences, Journal of Marketing, July, 53-70.

[13] Kardes, F. R. \&Kalyanaram, G.,1992. Order of Entry Effect on Consumer Memory and Judgment: an Information Integration Perspective, Journal of Marketing Research, XXIX (August), 343-357.

[14] Kerlinger, F.N.,1986. Foundations of Behavioral Research, Fort Worth, TX : Holt, Reinhart and Winston.

[15] KotlerPhiliph, 2015.Marketing Management, Editon XII, Salemba, Indonesia.

[16] Lambkin, M., 1988. Order of Entry and Performance in new Markets, Strategic Management Journal, 9, 127-140.

[17] Lieberman. M. B. \& Montgomery, D. B., 1988. First Mover Advantages, Strategic Management Journal, 9, 41-58.

[18] Mitchell, W.,1991. Dual Clocks: Entry Order Influence on Incumbent and Newcomer Market Share and Survival When Specialized Assets Retain Their Value, Strategic Management Journal, 12 (March) 85-100.

[19] Nerver, J. C. \& Stanley, F. S.,1990. The Effect of a Market orientation on Business Profitability, Journal of Marketing, 5 (October), 20-35.

[20] Robinson, W. T., Fornell, C. \& Sullivan, M., 1992.Are Market Pioneer Intrinsically Stronger Than Later Entrants? Strategic Management Journal, 13, 609-624.

[21] Robinson, W.T. \& Huff, L. C., 1994. The Impact of Lead Time and Years of Competitive Rivalry on Pioneer Market Share Advantages, Management Science, 40 (October), 1370-1377.

[22] Robinson, W.T., 1988. Sources of Market Pioneer Advantages: The case of Industrial Goods Industries, Journal of Marketing Research XXV (February), 87-94.

[23] Robinson, W. T. and Fornell, C., 1985. Source of Market Pioneer Advantages in Consumer Goods Industries, Journal of Marketing Research, August, 305-317.

[24] Sekaran, U. (1992). Research Methods for Business : A SkillBuilding Approach, Second edition, Jhon Wiley \& Sons, Inc.

[25] Srinivasan, K. (1988). Pioneering Versus Early Following in New Product Markets, ” unpublished PhD dissertation, University of California, Los Angeles. 
[26] Shankar, V., Carpenter, G.S. \&Krishnamurthi, L. (1998).Late Mover Advantage: How Innovative Late Entrants Outsell Pioneers, Journal of Marketing Research, February, (1-14).

[27] Szymanski, D. M., Troy, L. C. \&Bharadwaj, S. G. (1995).Order of Entry and Business Performance: An Empirical Synthesis and Reexamination, Journal of Marketing, 59 (October)

17-33. 